\title{
Perlakuan Rizobakteri Terhadap Patogen Terbawa Benih dan Peranannya Sebagai Pemacu Pertumbuhan Tanaman Terhadap Viabilitas dan Vigor Benih Pada Dua Varietas Cabai Merah (Capsicum annuum L.)
}

\author{
Effectiveness of rizobacteria inhibition to Pathogens Carried Seed In vitro and \\ its role as plant growth promoting to seed viability and vigor in two varieties \\ red chili pepper (Capsicum annuum L.)
}

\author{
Malikul Mulki ${ }^{1}$, Halimursyadah $^{1}$ dan Syamsuddin $^{1 *}$ \\ ${ }^{1}$ Program Studi Agroteknologi, Fakultas Pertanian, Universitas Syiah Kuala
}

\begin{abstract}
Abstrak. Rendahnya produksi tanaman cabai merah di Indonesia antara lain disebabkan oleh serangan penyakit dan tidak tersedianya benih yang bermutu tinggi atau memiliki viabilitas yang rendah. Perlakuan benih secara hayati (Biological Seed Treatment) menggunakan rizobakteri merupakan salah satu inovasi yang dikembangkan untuk pengendalian penyakit dan pemacu pertumbuhan tanaman. Penelitian ini telah dilaksanakan di Laboratorium Ilmu dan Teknologi Benih Program Studi Agroteknologi Fakultas Pertanian Unsyiah. Penelitian dimulai sejak bulan Mei hingga Juli 2017. Penelitian ini menggunakan Rancangan Acak Lengkap (RAL) pola non faktorial pada percobaan I terdiri dari 18 perlakuan yang diulang sebanyak 3 kali sehingga didapatkan masing-masing 54 satuan percobaan terhadap patogen Phytophthora capsici dan 54 satuan percobaan terhadap patogen Colletotrichum capsici sehingga didapatkan 108 total satuan percobaan. Pada perobaan II menggunakan Rancangan Acak Lengkap (RAL) pola faktorial terdiri dari 19 perlakuan rizobakteri dan 2 perlakuan varietas yang diulang sebanyak 2 kali Sehingga terdapat 38 kombinasi perlakuan yang terdiri dari 48 unit percobaan dengan 25 unit tanaman di setiap perlakuan. Hasil penelitian percobaan I menunjukkan bahwa isolat SRK 5(1) yang berasal dari Desa Serulee Kayu, Kecamatan Bukit, Kabupaten Bener Meuriah mampu menekan pertumbuhan patogen $C$. capsici dengan nilai daya hambat $82,22 \%$ dan terhadap patogen P. capsici $71,11 \%$. Hasil percobaan II menunjukkan bahwa rizobakteri yang efektif sebagai pemacu pertumbuhan tanaman (RPPT) terhadap proses perkecambahan benih cabai merah dalam meningkatkan viabilitas dan vigor benih terhadap potensi tumbuh maksimum dan daya berkecambah adalah isolat KTK 8(5) dimana varietas PM999 lebih baik dibandingkan varietas Taro, namun isolat yang berbeda yaitu SRK 5(1), HWI 4(1) dan BS3 5(3) mampu meningkatkan indeks vigor pada varietas Taro yang lebih tinggi dibandingkan dengan varietas PM999. Sedangkan pengaruh perlakuan rizobakteri terhadap pertumbuhan bibit cabai merah belum menunjukkan peningkatan yang signifikan terhadap dua varietas yang dicobakan.
\end{abstract}

Kata kunci : Rizobakteri, Agens biokontrol, RPPT, Colletotrichum capsici, Phytophthora capsici

\begin{abstract}
The low production of red pepper plants in Indonesia is partly caused by disease attacks and unavailability of high quality seeds or have low viability. Biological Seed Treatment using rhizobacteria is one of the innovations developed for disease control and growth of plants. This research has been carried out in Agricultural Science and Technology Laboratory of Agrotechnology Study Program Faculty of Agriculture Unsyiah. The study was conducted from May to July 2017. This study used a Completely Randomized Design (RAL) of non factorial pattern in experiment I consisted of 18 treatments repeated 3 times so that each of 54 experiments on pathogenic Phytophthora capsici and 54 units of experiments was obtained pathogen Colletotrichum capsici to obtain 108 total unit of experiment. In the second experiment using Completely Randomized Design (RAL) the factorial pattern consisted of 19 rizobacterial treatments and 2 repeated treatments of varieties 2 times. Thus there were 38 treatment combinations consisting of 48 experimental units with 25 plant units in each treatment. The result of experiment I showed that isolate SRK 5 (1) from Serulee Kayu Village, Bukit Subdistrict, Bener Meuriah Regency was able to suppress the growth of C. capsici pathogens with $82.22 \%$ inhibition and against $P$. capsici $71.11 \%$. The results of experiment II showed that rizobakteri effective as plant growth enhancer (RPPT) to germination process of red chilli seedlings in increasing seed viability and vigor to maximum growth potential and germination is isolate KTK 8 (5) where the varieties of PM999 is better than Taro varieties, but the different isolates of SRK 5 (1), HWI 4 (1) and BS3 5 (3) were able to increase the vigor index on higher Taro varieties compared to the PM999 varieties. While the effect of rizobacterial treatment on the growth of red chili seedlings has not shown a significant increase in the two varieties tested.
\end{abstract}

Key words : Rizobacteria, Biocontrol agents, RPPT, Colletotrichum capsici, Phytophthora capsici 


\section{PENDAHULUAN}

Cabai merah (Capsicum annuum L.) merupakan salah satu komoditas hortikultura unggulan terbesar dari golongan sayur-sayuran karena memiliki harga jual yang tinggi dan memiliki beberapa manfaat untuk kesehatan diantaranya yaitu sumber kalori, protein, lemak, kabohidarat, kalsium, vitamin A, B1 dan vitamin C. Masyarakat umumnya menggunakan cabai merah sebagai bahan baku keperluan rumah tangga, selain itu cabai merah juga dapat digunakan untuk keperluan industri seperti industri makanan dan industri obat-obatan (Agung, 2007).

Rendahnya produksi tanaman cabai merah di Indonesia disebabkan antara lain tidak tersedianya benih yang bermutu tinggi atau memiliki viabilitas yang rendah. Varietas unggul seperti Taro dan PM999 memiliki sifat genetik yang berbeda dalam mempengaruhi pertumbuhan dan kemampuan tanaman untuk beradaptasi terhadap lingkungan (Prajnanta, 2004). Di samping itu rendahnya kualitas dan kuantitas tanaman cabai merah di Indonesia juga tidak terlepas dari kurangnya kesadaran petani dalam memperhatikan mutu benih yang digunakan dan gangguan dari organisme pengganggu tanaman khususnya penyakit yang dapat menyerang tanaman pada fase pembibitan (Duriat et al, 2007).

Perlakuan benih untuk mengendalikan penyakit yang disebabkan oleh cendawan Colletotrichum capsici dan Phytophthora capsici pada umumnya dilakukan dengan penggunaan fungisida sintetis dengan mengaplikasikan langsung pada benih yang terserang. Namun, pengendalian secara kimia sudah mulai dikurangi karena dapat menyebabkan resistensi baru bagi perkembangan patogen dan dalam bentuk kesadaran akan kesehatan serta bahaya lingkungan. Untuk itu perlu dilakukan pengendalian penyakit tanaman cabai secara hayati yang ramah lingkungan dengan menggunakan agens biokontrol yang memiliki antibiosis dalam menekan jumlah patogen yang dapat menyerang tanaman (Agrios, 2005).

Sehubungan dengan efektifitas pengendalian penyakit antraknosa dan busuk phytophthora pada tanaman cabai merah menggunakan agen biokontrol khususnya dari kelompok rizobakteri isolat tanaman tomat, rizobakteri yang mampu bersimbiosis dengan akar tanaman juga mempunyai peran penting dalam pemacu pertumbuhan tanaman (RPPT). Hal tersebut dicapai dengan mobilisasi hara, produksi hormon tumbuh, fiksasi nitrogen atau pengaktifan mekanisme ketahanan terhadap penyakit sehingga dapat menjadi peluang baru sebagai pupuk hayati (Thakuria et al., 2004).

\section{METODE PENELITIAN}

\section{Tempat dan Waktu Penelitian}

Penelitian ini dilaksanakan di Laboratorium Ilmu dan Teknologi Benih, Program Studi Agroteknologi Fakultas Pertanian Universitas Syiah Kuala Darussalam Banda Aceh. Penelitian telah dilaksanakan dari bulan Mei hingga bulan Juli 2017.

\section{Alat dan Bahan Penelitian}

Alat yang digunakan dalam penelitian ini yaitu Laminar Air Flow Cabinet, jarum ose, erlenmeyer, beaker glass, pinset, lampu bunsen, petridish, gelas ukur, ruang inkubasi, autoclave, timbangan analitik, oven listrik, tray, meja pembibitan, sprayer, meteran, jangka sorong, ayakan 9 mesh dan spektrofotometer. Sedangkan Bahan yang digunakan dalam penelitian ini adalah benih cabai merah varietas Taro dan PM999 masing-masing sebanyak 1 sachet, isolat patogen Phytophthora capsici dan Colletotrichum capsici, isolat Rizobakteri yang berasal dari tanaman tomat sebanyak 18 jenis, PDA (Potato Dextrose Agar) 3 L, 
aluminium foil 1 unit, alkohol 96\% 2 L, plastic wrap 1 unit, plastik tahan panas, karet, aquadest $10 \mathrm{~L}$, tisu, tanah, dan pupuk kandang.

\section{Rancangan Penelitian}

Dalam penelitian ini dilakukan melalui 2 (dua) percobaan, dimana percobaan I menggunakan Rancangan Acak Lengkap (RAL) pola non faktorial dan percobaan II menggunakan Rancangan Acak Lengkap (RAL) pola faktorial. Pada percobaan I faktor yang diteliti adalah rizobakteri sebanyak 18 isolat yaitu SRK 5(1) $\left(\mathrm{R}_{1}\right)$, SRK 5(2) $\left(\mathrm{R}_{2}\right)$, SRK 5(3)

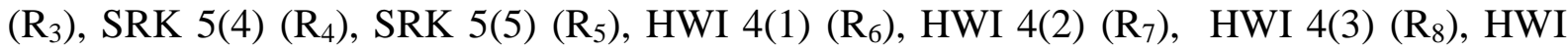

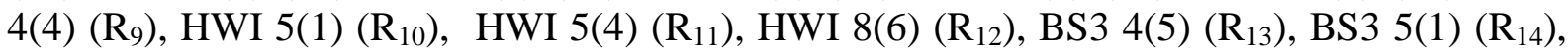
BS3 5(3) $\left(\mathrm{R}_{15}\right)$, BS3 5(4) $\left(\mathrm{R}_{16}\right)$, KTK 8(4) $\left(\mathrm{R}_{17}\right)$, KTK 8(5) $\left(\mathrm{R}_{18}\right)$ dengan 3 kali ulangan didapatkan 54 satuan percobaan terhadap patogen Phytophthora capsici dan 54 satuan percobaan terhadap patogen Colletotrichum capsici sehingga didapatkan 108 total satuan percobaan. Sedangkan pada percobaan II menggunakan Rancangan Acak Lengkap (RAL) pola faktorial dengan perlakuan rizobakteri yang sama yaitu 18 dan perlakuan varietas Taro $\left(\mathrm{V}_{1}\right)$ dan PM999 $\left(\mathrm{V}_{2}\right)$ yang diulang sebanyak 2 kali Sehingga terdapat 38 kombinasi perlakuan yang terdiri dari 48 unit percobaan dengan 25 unit tanaman di setiap perlakuan.

\section{Prosedur Penelitian}

\section{Percobaan I}

\section{Pembuatan media PDA (Potato Dextrose Agar)}

Kentang sebanyak $200 \mathrm{~g}$ dicuci bersih dan dikupas kulitnya. Kentang dipotong kecilkecil berbentuk persegi kemudian direbus dengan aquadest sebanyak $500 \mathrm{ml}$ sampai tekstur kentang empuk. Hal ini dapat diketahui dengan menusuk kentang, jika di tusuk terasa lunak, berarti kentang telah mengeluarkan sarinya lalu disaring ekstraknya. Aquadest steril dipanaskan sebanyak $500 \mathrm{ml}$ bersama dengan agar sebanyak $20 \mathrm{~g}$ dan dextrose sebanyak $20 \mathrm{~g}$, aduk hingga kedua bahan tersebut larut. Jika sudah larut dengan baik, disatukan larutan agar dengan ekstrak kentang yang telah disaring ke dalam beaker glass berukuran 1 liter. Larutan PDA dimasukkan ke dalam erlenmayer kemudian ditutup dengan menggunakan aluminium foil dan plastik sebanyak 2 lapis serta diikat dengan 3 karet gelang. Larutan PDA disterilkan didalam autoclave selama 15 menit, suhu $121-124^{\circ} \mathrm{C}$. Setelah disterilisasi, biarkan larutan PDA tersebut hingga suhunya turun menjadi hangat $\left(10-20^{\circ} \mathrm{C}\right)$ dan siap dituang ke dalam petridish. Disimpan larutan PDA tersebut hingga agarnya memadat dan siap digunakan (Panjaitan et al., 2011).

\section{Pengujian kultur ganda secara in vitro}

Rizobakteri kandidat agens biokontrol hasil isolasi dari sistem perakaran tanaman tomat sehat, dilakukan pengujian kemampuan antagonismenya melawan patogen terbawa benih menggunakan teknik kultur ganda. Kultur ganda dipersiapkan dengan cara menempatkan potongan kecil $(0.5 \mathrm{~mm})$ patogen Phytophthora capsici dan Colletotrichum capsici, dan potongan rizobakteri ditempatkan pada media PDA dalam petridish. Jarak antara titik inokulasi patogen dan rizobakteri yaitu $3 \mathrm{~cm}$ (Ibrahim et al., 2014). Pengujian diinkubasikan pada temperatur ruangan $\left(28-29^{\circ} \mathrm{C}\right)$, selanjutnya diamati tiap hari selama 7 hari.

\section{Percobaan II}

\section{Persiapan benih}

Benih yang akan digunakan adalah benih cabai merah varietas Taro dan PM999 Cap Panah Merah yang diperoleh dari toko Sarana Tani di Lambaro Aceh Besar. Benih ini 
merupakan varietas unggul dan masih dalam status masa berlaku label hasil pengujian dari produsen benihnya.

\section{Persiapan Isolat Rizobakteri Pemacu Pertumbuhan Tanaman (RPPT)}

Rizobakteri yang digunakan merupakan isolat dari hasil isolasi yang dilakukan oleh peneliti sebelumnya. Isolat rizobakteri dikembangbiakkan pada Potato Dextrose Agar (PDA), dan diinkubasi selama 48 jam, hingga koloni bakteri tumbuh dengan sempurna. Koloni bakteri yang tumbuh disuspensi dalam aquades steril $50 \mathrm{ml}$. Larutan suspensi bakteri yang telah siap, dihitung kerapatannya dengan menggunakan spektrofotometer sampai mencapai kerapatan populasi $10^{9} \mathrm{cfu} / \mathrm{ml}$ (Bai et al., 2002).

\section{Perlakuan Benih dengan Rizobakteri Pemacu Pertumbuhan Tanaman (RPPT)}

Benih cabai merah varietas Taro dan PM999 masing-masing sebanyak 25 benih terlebih dahulu dibersihkan dari seed treatment sebelumnya (warna merah pada benih) dengan cara direndam selama 1×24 jam dalam air menggunakan aerator, selanjutnya benih ditiriskan menggunaan saringan. Benih yang telah dibersihkan direndam dengan suspensi rizobakteri 50 ml selama 1x24 jam dan siap digunakan untuk pembibitan.

\section{Penanaman Benih}

Pada tahap ini benih yang telah mendapatkan perlakuan rizobakteri dikecambahkan di dalam tray berukuran $27 \times 56 \times 5 \mathrm{~cm}$ (panjang x lebar x tinggi) menggunakan media tanam berupa campuran tanah dan pupuk kandang steril (2:1). Media tanah dan pupuk kandang sebelumnya diayak dengan ayakan 9 mesh. Benih ditanam sebanyak 25 unit pada setiap perlakuan.

\section{Parameter Pengamatan}

Parameter yang diamati adalah percobaan I : Efektifitas daya hambat rizobakteri. Sedangkan pada percobaan II : viabilitas dan vigor benih meliputi, Potensi tumbuh maksimum (PTM), Daya berkecambah (DB), Indeks vigor (IV), Keserempakan tumbuh (Kst), Kecepatan tumbuh relatif (Kct-R), Waktu yang dibutuhkan untuk mencapai $50 \%$ perkecambahan total relatif $\left(\mathrm{T}_{50}\right)$ dan parameter pertumbuhan bibit meliputi tinggi bibit, diameter batang, jumlah daun, dan berangkasan kering

\section{Analisis Data Penelitian}

Data hasil pengamatan pada setiap peubah dianalisis dengan anova. Data yang menunjukkan perbedaan yang nyata pada Fhitung maka dilanjutkan dengan Uji Beda Nyata Jujur(BNJ) pada taraf 0,05

\section{HASIL DAN PEMBAHASAN}

\section{Percobaan I}

\section{Kemampuan Daya Hambat Rizobakteri terhadap Patogen C.capsici dan P. capsici}

Berdasarkan hasil pengamatan persentase daya hambat rizobakteri (Tabel 1) terhadap pertumbuhan koloni patogen terbawa benih cabai merah secara in vitro menunjukkan bahwa 1 jenis isolat rizobakteri paling efektif adalah SRK 5(1) tergolong dalam aktivitas sangat tinggi yaitu $82,22 \%$ daya hambatnya terhadap 2 patogen yang berbeda, 6 isolat dengan aktivitas daya hambat tinggi yaitu SRK 5(3), HWI 5(4), HWI 8(6), BS3 4(5), BS3 5(1) dan BS3 5(4) dan terdapat 11 jenis isolat yang daya hambatnya rendah yaitu SRK 5(2), SRK 5(4), SRK 5(5), HWI 4(1), HWI 4(2), HWI 4(3), HWI 4(4), HWI 5(1), BS3 5(3), KTK 8(4) dan KTK 
8(5) kurang dari 50\%. Hasil penelitian sebelumnya melaporkan bahwa isolat SRK 5(1) dapat menghambat patogen Fusarium oxysporum dengan nilai daya hambat sebesar $76,66 \%$ dan Phytium sp. dengan nilai 66,66\% (Royanti, 2017). Proses antagonisme agens biokontrol pada umumnya dilakukan dengan cara memproduksi senyawa antimikroba seperti nitrogen dan zat besi melalui produksi siderof, kompetisi terhadap tempat infeksi inaktifasi faktor perkecambahan spora dan parasitisme yang dapat melibatkan produksi enzim seperti , $\beta$ - 1,3 glucanase yang dapat melilis dinding sel patogen (Harman et al., 2004).

Tabel 1. Rata-rata Nilai Persentase (\%) Daya Hambat Isolat Rizobakteri Kandidat Agens Biokontrol terhadap Pertumbuhan koloni patogen terbawa Benih Cabai Merah

\begin{tabular}{ccccc}
\hline \multirow{2}{*}{ Agens Biokontrol } & \multicolumn{5}{c}{ Persentase Daya Hambat (\%) } \\
\cline { 2 - 5 } & C. capsici & Aktivitas & P. capsici & Aktivitas \\
\hline SRK 5 (1) & $82,22 \mathrm{e}$ & ++++ & $71,11 \mathrm{~d}$ & +++ \\
SRK 5 (2) & $34,44 \mathrm{~b}$ & + & $12,22 \mathrm{a}$ & + \\
SRK 5 (3) & $71,11 \mathrm{de}$ & +++ & $68,89 \mathrm{~d}$ & + \\
SRK 5 (4) & $42,22 \mathrm{bc}$ & + & $30,00 \mathrm{abc}$ & + \\
SRK 5 (5) & $38,89 \mathrm{bc}$ & + & $31,11 \mathrm{abc}$ & + \\
HWI 4 (1) & $39,99 \mathrm{bc}$ & + & $36,66 \mathrm{bc}$ & + \\
HWI 4 (2) & $15,55 \mathrm{a}$ & + & $13,33 \mathrm{a}$ & + \\
HWI 4 (3) & $14,44 \mathrm{a}$ & + & $33,33 \mathrm{a}$ & + \\
HWI 4 (4) & $42,22 \mathrm{bc}$ & + & $25,55 \mathrm{abc}$ & + \\
HWI 5 (1) & $50,00 \mathrm{c}$ & + & $70,00 \mathrm{~d}$ & +++ \\
HWI 5 (4) & $71,11 \mathrm{de}$ & +++ & $52,22 \mathrm{~cd}$ & ++ \\
HWI 8 (6) & $65,55 \mathrm{~d}$ & +++ & $71,11 \mathrm{~d}$ & ++ \\
BS3 4 (5) & $71,11 \mathrm{de}$ & +++ & $65,55 \mathrm{~d}$ & ++ \\
BS3 5 (1) & $64,44 \mathrm{~d}$ & +++ & $14,44 \mathrm{ab}$ & + \\
BS3 5 (3) & $16,66 \mathrm{a}$ & + & $67,77 \mathrm{~d}$ & + \\
BS3 5 (4) & $71,11 \mathrm{de}$ & +++ & $23,33 \mathrm{ab}$ & + \\
KTK 8 (4) & $11,11 \mathrm{a}$ & + & $30,00 \mathrm{abc}$ & + \\
KTK 8 (5) & $8,88 \mathrm{a}$ & + & & 23,29 \\
\hline BNJ 0,05 & & 12,85 & &
\end{tabular}

Keterangan : Angka yang diikuti oleh huruf yang sama pada kolom yang sama berbeda tidak nyata pada Uji Beda Nyata Jujur (BNJ) $\alpha=0,05$. Aktivitas sangat tinggi $(++++=>75 \mathrm{DH})$, aktivitas tinggi $(+++=$ $61-75 \mathrm{DH})$, aktivitas sedang $(++=51-60 \mathrm{DH})$, aktivitas rendah $(+=<50 \mathrm{DH})$ dan tidak ada aktivitas $(-)$.

\section{Percobaan II}

\section{Kemampuan RPPT Terhadap Viabilitas, Vigor Benih dan Pertumbuhan Bibit}

Hasil analisis ragam (Uji F) menunjukkan bahwa perlakuan rizobakteri berpengaruh nyata terhadap viabilitas dan vigor benih pada tolok ukur potensi tumbuh maksimum, daya berkecambah, indeks vigor, keserempakan tumbuh, kecepatan tumbuh dan $\mathrm{T}_{50}$ dapat dilihat pada Tabel 2. Sedangkan pada tolok ukur pertumbuhan bibit, berpengaruh sangat nyata terhadap tinggi bibit, berpengaruh nyata terhadap jumlah daun dan diameter batang dan tidak berpengaruh pada berangkasan kering.Penelitian sebelumnya melaporkan bahwa penggunaan rizobakteri mampu memperbaiki kualitas dan meningkatkan perkecambahan benih (Sutariati dan Wahab, 2010). Safriani (2015) menambahkan bahwa perlakuan rizobakteri jenis $B$. stearothermophillus mampu meningkatkan nilai rata-rata potensi tumbuh maksimum mencapai $98,33 \%$ dan daya berkecambah $95,83 \%$ pada benih cabai merah.

Sutariati (2006) melaporkan bahwa perlakuan benih menggunakan rizobakteri jenis Serratia $s p$ yang memproduksi hormon IAA hanya dalam jumlah sedikit $24.16-27.98 \mathrm{~g} / \mathrm{ml}$ mampu meningkatkan tinggi bibit dan biomassa bibit cabai, sedangkan jenis rizobakteri Bacillus sp dan Pseudomonas sp yang menghasilkan IAA lebih banyak ternyata tidak mampu memacu pertumbuhan bibit cabai. Ahmad et al., (2005) menambahkan diantara isolat 
rizobakteri yang dievaluasi, isolat $P$. fluorescens mampu memproduksi IAA lebih banyak dibandingkan isolat Bacillus sp atau Serratia sp. Dalam penelitian ini isolat rizobakteri yang efektif pada tolok ukur viabilitas dan vigor benih tidak semuanya menunjukkan kemampuan yang sama pada tolok ukur pertumbuhan bibit.

Tabel 2. Rata-rata Nilai Viabilitas dan Vigor Benih Akibat Perlakuan Beberapa Rizobakteri

\begin{tabular}{cllllll}
\hline \multirow{2}{*}{ Rizobakteri } & \multicolumn{5}{c}{ Tolok ukur viabilitas dan vigor benih } \\
\cline { 2 - 6 } & PTM $(\%)$ & DB $(\%)$ & IV $(\%)$ & $\mathrm{K}_{\mathrm{ST}}(\%)$ & $\mathrm{K}_{\mathrm{CT}-\mathrm{R}(\%)}$ & $\mathrm{T}_{50}($ hari $)$ \\
\hline Kontrol & $84 \mathrm{a}-\mathrm{d}$ & $84 \mathrm{abc}$ & $28 \mathrm{abc}$ & $61 \mathrm{ab}$ & $71,25 \mathrm{abc}$ & $7,31 \mathrm{e}$ \\
SRK 5(1) & $97 \mathrm{~cd}$ & $97 \mathrm{c}$ & $63 \mathrm{e}$ & $79 \mathrm{ab}$ & $94,39 \mathrm{~d}$ & $5,15 \mathrm{a}$ \\
SRK 5(2) & $98 \mathrm{~cd}$ & $96 \mathrm{c}$ & $42 \mathrm{~b}-\mathrm{e}$ & $79 \mathrm{ab}$ & $81,42 \mathrm{~cd}$ & $5,96 \mathrm{a}-\mathrm{d}$ \\
SRK 5(3) & $98 \mathrm{~cd}$ & $97 \mathrm{c}$ & $66 \mathrm{e}$ & $79 \mathrm{ab}$ & $89,30 \mathrm{~cd}$ & $5,31 \mathrm{ab}$ \\
SRK 5(4) & $97 \mathrm{~cd}$ & $96 \mathrm{c}$ & $51 \mathrm{cde}$ & $81 \mathrm{ab}$ & $88,82 \mathrm{~cd}$ & $5,21 \mathrm{ab}$ \\
SRK 5(5) & $90 \mathrm{bcd}$ & $90 \mathrm{abc}$ & $48 \mathrm{~b}-\mathrm{e}$ & $74 \mathrm{ab}$ & $80,77 \mathrm{~cd}$ & $5,83 \mathrm{a}-\mathrm{d}$ \\
HWI 4(1) & $99 \mathrm{~d}$ & $99 \mathrm{c}$ & $52 \mathrm{cde}$ & $91 \mathrm{~b}$ & $91,84 \mathrm{~cd}$ & $5,97 \mathrm{a}-\mathrm{d}$ \\
HWI 4(2) & $92 \mathrm{bcd}$ & $88 \mathrm{abc}$ & $30 \mathrm{a}-\mathrm{d}$ & $82 \mathrm{ab}$ & $76,24 \mathrm{bcd}$ & $6,36 \mathrm{~b}-\mathrm{e}$ \\
HWI 4(3) & $95 \mathrm{~cd}$ & $95 \mathrm{c}$ & $48 \mathrm{~b}-\mathrm{e}$ & $78 \mathrm{ab}$ & $86,65 \mathrm{~cd}$ & $5,45 \mathrm{abc}$ \\
HWI 4(4) & $92 \mathrm{bcd}$ & $89 \mathrm{abc}$ & $41 \mathrm{~b}-\mathrm{e}$ & $81 \mathrm{ab}$ & $79,02 \mathrm{~cd}$ & $6,00 \mathrm{a}-\mathrm{d}$ \\
HWI 5(1) & $94 \mathrm{~cd}$ & $91 \mathrm{abc}$ & $46 \mathrm{~b}-\mathrm{e}$ & $82 \mathrm{ab}$ & $81,54 \mathrm{~cd}$ & $6,24 \mathrm{a}-\mathrm{e}$ \\
HWI 5(4) & $97 \mathrm{~cd}$ & $97 \mathrm{c}$ & $56 \mathrm{de}$ & $79 \mathrm{ab}$ & $88,74 \mathrm{~cd}$ & $5,70 \mathrm{a}-\mathrm{d}$ \\
HWI 8(6) & $88 \mathrm{bcd}$ & $86 \mathrm{abc}$ & $43 \mathrm{~b}-\mathrm{e}$ & $70 \mathrm{ab}$ & $72,91 \mathrm{abc}$ & $5,47 \mathrm{abc}$ \\
BS3 4(5) & $85 \mathrm{a}-\mathrm{d}$ & $85 \mathrm{abc}$ & $32 \mathrm{a}-\mathrm{d}$ & $71 \mathrm{ab}$ & $72,88 \mathrm{abc}$ & $6,26 \mathrm{a}-\mathrm{e}$ \\
BS3 5(1) & $76 \mathrm{ab}$ & $72 \mathrm{ab}$ & $23 \mathrm{ab}$ & $56 \mathrm{ab}$ & $57,80 \mathrm{ab}$ & $6,19 \mathrm{a}-\mathrm{e}$ \\
BS3 5(3) & $92 \mathrm{bcd}$ & $92 \mathrm{bc}$ & $34 \mathrm{bcd}$ & $86 \mathrm{~b}$ & $80,31 \mathrm{~cd}$ & $6,51 \mathrm{cde}$ \\
BS3 5(4) & $91 \mathrm{bcd}$ & $91 \mathrm{abc}$ & $54 \mathrm{cde}$ & $90 \mathrm{~b}$ & $84,87 \mathrm{~cd}$ & $5,79 \mathrm{a}-\mathrm{d}$ \\
KTK 8(4) & $81 \mathrm{abc}$ & $81 \mathrm{abc}$ & $46 \mathrm{~b}-\mathrm{e}$ & $69 \mathrm{ab}$ & $71,00 \mathrm{abc}$ & $5,89 \mathrm{a}-\mathrm{d}$ \\
KTK 8(5) & $70 \mathrm{a}$ & $70 \mathrm{a}$ & $6 \mathrm{a}$ & $46 \mathrm{a}$ & $53,14 \mathrm{a}$ & $6,76 \mathrm{de}$ \\
\hline BNJ 0,05 & 17,46 & 21,50 & 27,13 & 38,7 & 21,08 & 1,16 \\
\hline
\end{tabular}

Keterangan : Angka yang diikuti oleh huruf yang sama pada kolom yang sama berbeda tidak nyata pada Uji Beda Nyata Jujur (BNJ) $\alpha=0,05$.

Tabel 3. Rata-rata Nilai Pertumbuhan Bibit Akibat Perlakuan Beberapa Rizobakteri

\begin{tabular}{ccccc}
\hline & \multicolumn{4}{c}{ Tolok Ukur Pertumbuhan Bibit } \\
\cline { 2 - 5 } Rizobakteri & $\begin{array}{c}\text { Tinggi } \\
\text { Bibit }(\mathrm{cm})\end{array}$ & $\begin{array}{c}\text { Jumlah } \\
\text { Daun (helai) }\end{array}$ & $\begin{array}{c}\text { Diameter } \\
\text { Batang }(\mathrm{mm})\end{array}$ & $\begin{array}{c}\text { Berangkasan } \\
\text { Kering (g) }\end{array}$ \\
\hline Kontrol & $22,07 \mathrm{a}-\mathrm{c}$ & $6,70 \mathrm{ab}$ & $2,43 \mathrm{a}$ & 1,99 \\
SRK 5(1) & $26,04 \mathrm{~b}-\mathrm{d}$ & $7,03 \mathrm{ab}$ & $1,91 \mathrm{a}$ & 2,36 \\
SRK 5(2) & $31,19 \mathrm{~d}$ & $7,30 \mathrm{ab}$ & $2,33 \mathrm{a}$ & 2,21 \\
SRK 5(3) & $29,58 \mathrm{~d}$ & $8,08 \mathrm{ab}$ & $2,29 \mathrm{a}$ & 3,30 \\
SRK 5(4) & $29,63 \mathrm{~d}$ & $8,50 \mathrm{~b}$ & $2,17 \mathrm{a}$ & 3,31 \\
SRK 5(5) & $30,63 \mathrm{~d}$ & $7,63 \mathrm{ab}$ & $2,26 \mathrm{a}$ & 2,83 \\
HWI 4(1) & $29,52 \mathrm{~d}$ & $6,98 \mathrm{ab}$ & $2,15 \mathrm{a}$ & 3,21 \\
HWI 4(2) & $29,80 \mathrm{~d}$ & $7,30 \mathrm{ab}$ & $2,21 \mathrm{a}$ & 2,41 \\
HWI 4(3) & $29,99 \mathrm{~d}$ & $7,98 \mathrm{ab}$ & $2,22 \mathrm{a}$ & 2,75 \\
HWI 4(4) & $30,11 \mathrm{~d}$ & $7,28 \mathrm{ab}$ & $1,86 \mathrm{a}$ & 2,26 \\
HWI 5(1) & $28,59 \mathrm{~d}$ & $6,93 \mathrm{ab}$ & $1,87 \mathrm{a}$ & 2,95 \\
HWI 5(4) & $26,98 \mathrm{~cd}$ & $6,30 \mathrm{a}$ & $1,71 \mathrm{a}$ & 2,87 \\
HWI 8(6) & $20,52 \mathrm{ab}$ & $6,58 \mathrm{ab}$ & $2,63 \mathrm{a}$ & 2,67 \\
BS3 4(5) & $19,42 \mathrm{a}$ & $6,93 \mathrm{ab}$ & $2,62 \mathrm{a}$ & 2,78 \\
BS3 5(1) & $20,14 \mathrm{ab}$ & $7,60 \mathrm{ab}$ & $2,84 \mathrm{a}$ & 3,11 \\
BS3 5(3) & $19,81 \mathrm{ab}$ & $7,18 \mathrm{ab}$ & $2,81 \mathrm{a}$ & 2,95 \\
BS3 5(4) & $18,59 \mathrm{a}$ & $6,83 \mathrm{ab}$ & $3,53 \mathrm{a}$ & 3,71 \\
KTK 8(4) & $19,13 \mathrm{a}$ & $7,10 \mathrm{ab}$ & $2,90 \mathrm{a}$ & - \\
KTK 8(5) & $21,02 \mathrm{a}-\mathrm{c}$ & $7,38 \mathrm{ab}$ & $2,86 \mathrm{a}$ & 1,91 \\
\hline BNJ & 6,37 & 1,96 &
\end{tabular}

Keterangan : Angka yang diikuti oleh huruf yang sama pada kolom yang sama berbeda tidak nyata pada $\mathrm{Uj}_{\mathrm{j}}$ Beda Nyata Jujur (BNJ) $\alpha=0,05$. 
Figueiredo et al., (2010) melaporkan bahwa rizobakteri mampu mempengaruhi pertumbuhan tanaman melalui mekanisme secara langsung atau tidak langsung. Fiksasi nitrogen, produksi siderof, $\mathrm{HCN}$ dan fitohormon dapat meningkatkan toleransi tanaman terhadap cekaman lingkungan seperti kekeringan. Egamberdiyeva (2007) menambahkan kelompok rizobakteri Pseudomonas mampu menghasilkan panjang akar dan tinggi tanaman yang lebih baik dibandingkan tanpa perlakuan. Isolat Pseudomonas fueresncens juga dilaporkan efektif meningkatkan pertumbuhan tomat (Ramamoorthy et al., 2002), Bacillus megaterium pada tanaman mint (Kaymak et al., 2008) dan Serratia marcenscens pada jagung (Hameda et al., 2008).

\section{Kemampuan Varietas Terhadap Viabilitas, Vigor Benih dan Pertumbuhan Bibit}

Hasil analisis ragam (Uji F) menunjukkan bahwa perlakuan varietas berpengaruh nyata terhadap tolok ukur viabilitas dan vigor benih berdasarkan nilai rata-rata dari potensi tumbuh maksimum, daya berkecambah, indeks vigor dan $\mathrm{T}_{50}$ dapat dilihat pada tabel 3 . Sedangkan pada tolok ukur pertumbuhan bibit, berpengaruh nyata terhadap jumlah daun dan berangkasan kering namun tidak perbengaruh pada tinggi bibit dan diameter batang.

Tabel 4. Rata-rata Nilai Viabilitas dan Vigor Benih Akibat Perlakuan Dua Varietas Cabai Merah

\begin{tabular}{|c|c|c|c|c|c|c|}
\hline \multirow{2}{*}{ Varietas } & \multicolumn{6}{|c|}{ Tolok ukur viabilitas dan vigor benih } \\
\hline & PTM $(\%)$ & $\mathrm{DB}(\%)$ & IV $(\%)$ & $\mathrm{K}_{\mathrm{ST}}(\%)$ & $\mathrm{K}_{\mathrm{CT}}-\mathrm{R}(\%)$ & $\mathrm{T}_{50}$ (hari) \\
\hline Taro & $88,74 \mathrm{a}$ & $86,84 \mathrm{a}$ & $47,89 \mathrm{~b}$ & 74,74 & 78,45 & $5,84 \mathrm{a}$ \\
\hline PM 999 & $93,58 \mathrm{~b}$ & $93,37 \mathrm{~b}$ & $37,26 \mathrm{a}$ & 76,21 & 80,70 & $6,12 b$ \\
\hline BNJ 0,05 & 3,03 & 3,74 & 4,71 & - & - & 0,20 \\
\hline
\end{tabular}

Tabel 5. Rata-rata Nilai Pertumbuhan Bibit Akibat Perlakuan Dua Varietas Cabai Merah

\begin{tabular}{ccccc}
\hline \multirow{2}{*}{ Varietas } & \multicolumn{4}{c}{ Tolok Ukur Pertumbuhan Bibit } \\
\cline { 2 - 5 } & Tinggi & Jumlah & Diameter Batang \\
$(\mathrm{mm})$ & $\begin{array}{c}\text { Berangkasan } \\
\text { Kering }(\mathrm{g})\end{array}$ \\
\hline Taro & 25,18 & $7,06 \mathrm{a}$ & $2,47 \mathrm{a}$ & $2,60 \mathrm{a}$ \\
PM 999 & 25,63 & $7,42 \mathrm{~b}$ & $2,32 \mathrm{a}$ & $3,03 \mathrm{~b}$ \\
\hline BNJ & - & 0,31 & 0,28 & 0,40 \\
\hline
\end{tabular}

Keterangan : Angka yang diikuti oleh huruf yang sama pada kolom yang sama berbeda tidak nyata pada Uji Beda Nyata Jujur (BNJ) $\alpha=0,05$.

Hal ini menunjukkan bahwa pengaruh perlakuan rizobakteri terhadap semua variabel tergantung pada jenis varietas dikarenakan varietas PM 999 lebih baik sifat genetiknya, faktor internal benih (genetik) merupakan penyebab adanya perbedaan daya tumbuh benih antar varietas (Sadjad, 1999).

\section{Hubungan Antara Rizobakteri dan Varietas Cabai Merah Terhadap Viabilitas dan Vigor Benih}

Tabel 6 dan 7 menunjukkan bahwa berdasarkan perlakuan tolok ukur viabilitas dan vigor benih, berpengaruh sangat nyata terhadap potensi tumbuh maksimum, daya berkecambah, indeks vigor, kecepatan tumbuh relatif dan waktu yang dibutuhkan untuk mencapai $50 \%$ perkecambahan, namun tidak berpengaruh nyata pada keserempakan tumbuh. Sedangkan pada tolok ukur pertumbuhan bibit (Tabel 8), berpengaruh sangat nyata terhadap tinggi bibit dan berpengaruh nyata terhadap jumlah daun, namun tidak berpengaruh terhadap diameter batang dan berangkasan kering. 
Tabel 6. Rata-rata Interaksi antara Rizobakteri dan Varietas terhadap Nilai Viabilitas dan Vigor

\begin{tabular}{|c|c|c|c|c|c|c|}
\hline \multirow{3}{*}{ Perlakuan } & \multicolumn{6}{|c|}{ Tolok ukur viabilitas dan vigor benih } \\
\hline & \multicolumn{2}{|c|}{$\operatorname{PTM}(\%)$} & \multicolumn{2}{|c|}{$\mathrm{DB}(\%)$} & \multicolumn{2}{|c|}{ IV $(\%)$} \\
\hline & Taro & PM999 & Taro & PM999 & Taro & PM999 \\
\hline Kontrol & $84 \mathrm{bcA}$ & $84 \mathrm{abA}$ & $84 \mathrm{bA}$ & $84 \mathrm{abA}$ & 28 abcA & 28 abcA \\
\hline SRK 5(1) & $98 \mathrm{cA}$ & $96 \mathrm{bA}$ & $98 \mathrm{bA}$ & $96 \mathrm{abA}$ & $90 \mathrm{fB}$ & 36 abcA \\
\hline SRK 5(2) & $92 \mathrm{bcA}$ & $100 \mathrm{bA}$ & $92 \mathrm{bA}$ & $100 \mathrm{bA}$ & 44 a-eA & $40 \mathrm{abcA}$ \\
\hline SRK 5(3) & $96 \mathrm{bcA}$ & $98 \mathrm{bA}$ & $96 \mathrm{bA}$ & $98 \mathrm{abA}$ & 80 efA & $52 \mathrm{bcA}$ \\
\hline SRK 5(4) & $98 \mathrm{cA}$ & $96 \mathrm{bA}$ & $98 \mathrm{bA}$ & $94 \mathrm{abA}$ & $64 c-f A$ & 38 abcA \\
\hline SRK 5(5) & $90 \mathrm{bcA}$ & $90 \mathrm{abA}$ & $90 \mathrm{bA}$ & $90 \mathrm{abA}$ & $52 \mathrm{~b}-\mathrm{fA}$ & 44 abcA \\
\hline HWI 4(1) & $100 \mathrm{cA}$ & $98 \mathrm{bA}$ & $100 \mathrm{bA}$ & $98 \mathrm{abA}$ & 76 defB & 28 abcA \\
\hline HWI 4(2) & $84 \mathrm{bcA}$ & $94 \mathrm{bA}$ & $84 \mathrm{bA}$ & $92 \mathrm{abA}$ & 40 a-eA & $20 \mathrm{abA}$ \\
\hline HWI 4(3) & $90 \mathrm{bcA}$ & $100 \mathrm{bA}$ & $90 \mathrm{bA}$ & $100 \mathrm{bA}$ & $58 \mathrm{~b}-\mathrm{fA}$ & 38 abcA \\
\hline HWI 4(4) & $86 \mathrm{bcA}$ & $92 \mathrm{abA}$ & $86 \mathrm{bA}$ & $92 \mathrm{abA}$ & $52 \mathrm{~b}-\mathrm{fA}$ & 30 abcA \\
\hline HWI 5(1) & $92 \mathrm{bcA}$ & $90 \mathrm{abA}$ & $92 \mathrm{bA}$ & $90 \mathrm{abA}$ & $42 \mathrm{a}-\mathrm{eA}$ & $50 \mathrm{abcA}$ \\
\hline HWI 5(4) & $94 \mathrm{bcA}$ & $100 \mathrm{bA}$ & $94 \mathrm{bA}$ & $100 \mathrm{bA}$ & $58 \mathrm{~b}-\mathrm{fA}$ & $54 \mathrm{bA}$ \\
\hline HWI 8(6) & $76 \mathrm{bcA}$ & $96 \mathrm{bA}$ & $76 \mathrm{abA}$ & $96 \mathrm{abA}$ & 32 abcA & $54 \mathrm{bA}$ \\
\hline BS3 4(5) & $80 \mathrm{bcA}$ & $90 \mathrm{abA}$ & $80 \mathrm{bA}$ & $90 \mathrm{abA}$ & $34 \mathrm{a}-\mathrm{dA}$ & 30 abcA \\
\hline BS3 5(1) & $78 \mathrm{bcA}$ & $66 \mathrm{aA}$ & $78 \mathrm{bA}$ & $66 \mathrm{aA}$ & $16 \mathrm{abA}$ & 30 abcA \\
\hline BS3 5(3) & $92 \mathrm{bcA}$ & $92 \mathrm{abA}$ & $92 \mathrm{bA}$ & $92 \mathrm{abA}$ & $58 \mathrm{~b}-\mathrm{fB}$ & $10 \mathrm{abA}$ \\
\hline BS3 5(4) & $90 \mathrm{bcA}$ & $92 \mathrm{abA}$ & $90 \mathrm{bA}$ & $92 \mathrm{abA}$ & $58 \mathrm{~b}-\mathrm{fA}$ & $50 \mathrm{abcA}$ \\
\hline KTK 8(4) & $70 \mathrm{abA}$ & $92 \mathrm{abA}$ & $70 \mathrm{abA}$ & $92 \mathrm{abA}$ & $24 \mathrm{abcA}$ & $68 \mathrm{bB}$ \\
\hline KTK 8(5) & $44 \mathrm{aA}$ & $96 \mathrm{bB}$ & $44 \mathrm{aA}$ & $96 \mathrm{abB}$ & $4 \mathrm{aA}$ & $8 \mathrm{aA}$ \\
\hline BNJ 0,05 & \multicolumn{2}{|c|}{27,57} & \multicolumn{2}{|c|}{33,97} & \multicolumn{2}{|c|}{42,87} \\
\hline
\end{tabular}

Keterangan : Angka yang diikuti oleh huruf yang sama pada kolom yang sama berbeda tidak nyata pada taraf 0,05 (Uji BNJ). Huruf kecil dibaca vertikal dan huruf besar dibaca horizontal.

Tabel 7. Rata-rata Interaksi antara Rizobakteri dan Varietas terhadap Nilai Viabilitas dan Vigor

\begin{tabular}{|c|c|c|c|c|c|c|}
\hline \multirow{3}{*}{ Perlakuan } & \multicolumn{6}{|c|}{ Tolok ukur viabilitas dan vigor benih } \\
\hline & \multicolumn{2}{|c|}{$\mathrm{K}_{\mathrm{ST}}(\%)$} & \multicolumn{2}{|c|}{$\mathrm{K}_{\mathrm{CT}}-\mathrm{R}(\%)$} & \multicolumn{2}{|c|}{$\mathrm{T}_{50}$ (hari) } \\
\hline & Taro & PM999 & Taro & PM999 & Taro & PM999 \\
\hline Kontrol & 48 & 74 & 70,04 bcdA & $72,46 \mathrm{abA}$ & $7,73 \mathrm{bA}$ & 6,89 bcdA \\
\hline SRK 5(1) & 92 & 66 & $112,96 \mathrm{eB}$ & $75,82 \mathrm{abA}$ & $4,15 \mathrm{aA}$ & $6,14 \mathrm{a}-\mathrm{dB}$ \\
\hline SRK 5(2) & 66 & 92 & 77,06 bcdA & $85,78 \mathrm{abA}$ & $5,76 \mathrm{aA}$ & $6,16 \mathrm{a}-\mathrm{dA}$ \\
\hline SRK 5(3) & 70 & 88 & 89,62 b-eA & $88,98 \mathrm{bA}$ & $5,56 \mathrm{aA}$ & $5,06 \mathrm{abA}$ \\
\hline SRK 5(4) & 92 & 70 & $99,04 \mathrm{deA}$ & $78,60 \mathrm{abA}$ & $5,16 \mathrm{aA}$ & 5,26 abcA \\
\hline SRK 5(5) & 86 & 62 & $86,61 \mathrm{~b}-\mathrm{eA}$ & $74,93 \mathrm{abA}$ & $5,63 \mathrm{aA}$ & $6,03 \mathrm{a}-\mathrm{dA}$ \\
\hline HWI 4(1) & 94 & 88 & $101,76 \mathrm{de} A$ & $81,92 \mathrm{abA}$ & $5,18 \mathrm{aA}$ & $6,75 \mathrm{a}-\mathrm{dA}$ \\
\hline HWI 4(2) & 84 & 80 & 78,46 bcdA & $74,02 \mathrm{abA}$ & $5,58 \mathrm{aA}$ & $7,13 \mathrm{cdA}$ \\
\hline HWI 4(3) & 84 & 72 & $92,15 \mathrm{cde} A$ & $81,14 \mathrm{abA}$ & $5,05 \mathrm{aA}$ & 5,84 a-dA \\
\hline HWI 4(4) & 78 & 84 & 79,45 bcdA & $78,59 \mathrm{abA}$ & $5,59 \mathrm{aA}$ & $6,40 \mathrm{a}-\mathrm{dA}$ \\
\hline HWI 5(1) & 78 & 86 & 83,16 b-eA & $79,92 \mathrm{abA}$ & $6,97 \mathrm{bA}$ & $5,50 \mathrm{a}-\mathrm{dA}$ \\
\hline HWI 5(4) & 68 & 90 & 90,40 b-eA & $87,08 \mathrm{abA}$ & $5,51 \mathrm{aA}$ & 5,88 a-dA \\
\hline HWI 8(6) & 84 & 56 & $63,37 \mathrm{abcA}$ & $82,44 \mathrm{abA}$ & $6,04 \mathrm{abA}$ & $4,90 \mathrm{aA}$ \\
\hline BS3 4(5) & 68 & 74 & $72,12 \mathrm{bcdA}$ & $73,64 \mathrm{abA}$ & $6,08 \mathrm{abA}$ & 6,44 a-dA \\
\hline BS3 5(1) & 64 & 48 & 61,33 abcA & $54,27 \mathrm{aA}$ & $6,73 \mathrm{bA}$ & 5,64 a-dA \\
\hline BS3 5(3) & 90 & 82 & 89,28 b-eA & $71,34 \mathrm{abA}$ & $5,58 \mathrm{aA}$ & $7,43 \mathrm{dA}$ \\
\hline BS3 5(4) & 88 & 92 & 86,02 b-eA & $83,72 \mathrm{abA}$ & $5,58 \mathrm{aA}$ & 5,99 a-dA \\
\hline KTK 8(4) & 56 & 82 & $57,71 \mathrm{abA}$ & $84,28 \mathrm{abA}$ & $6,45 \mathrm{bA}$ & 5,33 abcA \\
\hline KTK 8(5) & 30 & 62 & $33,82 \mathrm{aA}$ & $72,46 \mathrm{abB}$ & $6,50 \mathrm{bA}$ & $7,02 \mathrm{cdA}$ \\
\hline BNJ 0,05 & \multicolumn{2}{|c|}{ - } & \multicolumn{2}{|c|}{33,32} & \multicolumn{2}{|c|}{1,95} \\
\hline
\end{tabular}

Keterangan : Angka yang diikuti oleh huruf yang sama pada kolom yang sama berbeda tidak nyata pada taraf 0,05 (Uji BNJ). Huruf kecil dibaca vertikal dan huruf besar dibaca horizontal.

Selain menghasilkan IAA sebagai pemacu pertumbuhan tanaman, dugaan lainnya adalah kemampuan rizobakteri dalam melarutkan fosfat. Hasil penelitian Sutariati et al., (2006) beberapa isolat rizobakteri kelompok B. alvei dan B. subtilis terbukti mampu 
melarutkan fosfat namun tidak dapat memacu pertumbuhan bibit. Namun, isolat kelompok Serratia semuanya tidak mempunyai kemampuan melarutkan fosfat tetapi mampu memacu pertumbuhan bibit cabai melebihi pertumbuhan bibit tanpa perlakuan rizobakteri

Tabel 8. Rata-rata Interaksi antara Rizobakteri dan Varietas terhadap Pertumbuhan Bibit

\begin{tabular}{|c|c|c|c|c|c|c|c|c|}
\hline \multirow{3}{*}{ Perlakuan } & \multicolumn{8}{|c|}{ Tolok ukur Pertumbuhan Bibit } \\
\hline & \multicolumn{2}{|c|}{$\begin{array}{l}\text { Tinggi } \\
\text { Bibit }\end{array}$} & \multicolumn{2}{|c|}{$\begin{array}{c}\text { Jumlah } \\
\text { Daun }\end{array}$} & \multicolumn{2}{|c|}{$\begin{array}{c}\text { Diameter } \\
\text { Batang }\end{array}$} & \multicolumn{2}{|c|}{$\begin{array}{c}\text { Berangkasan } \\
\text { Kering }\end{array}$} \\
\hline & Taro & PM 999 & Taro & PM 999 & Taro & PM 999 & Taro & PM 999 \\
\hline Kontrol & $15,29 \mathrm{aA}$ & $18,68 \mathrm{aA}$ & $5,95 \mathrm{aA}$ & $6,15 \mathrm{aA}$ & 3,39 & 1,47 & 2,21 & 1,76 \\
\hline SRK 5(1) & $17,21 \mathrm{abA}$ & $18,71 \mathrm{abA}$ & $6,30 \mathrm{aA}$ & $6,30 \mathrm{aA}$ & 1,76 & 2,06 & 2,00 & 2,71 \\
\hline SRK 5(2) & $18,59 \mathrm{abcA}$ & $19,25 \mathrm{abA}$ & $6,30 \mathrm{aA}$ & $6,60 \mathrm{abA}$ & 2,49 & 2,17 & 2,82 & 4,01 \\
\hline SRK 5(3) & 19,55 a-dA & $19,97 \mathrm{abA}$ & $6,40 \mathrm{aA}$ & $6,70 \mathrm{abA}$ & 2,11 & 2,46 & 2,11 & 2,30 \\
\hline SRK 5(4) & $20,15 \mathrm{a}-\mathrm{dA}$ & $19,98 \mathrm{abA}$ & $6,50 \mathrm{aA}$ & $6,80 \mathrm{abA}$ & 2,00 & 2,33 & 2,02 & 4,57 \\
\hline SRK 5(5) & 21,02 a-eA & $20,11 \mathrm{abA}$ & $6,70 \mathrm{aA}$ & $6,95 \mathrm{abA}$ & 2,26 & 2,25 & 2,57 & 4,04 \\
\hline HWI 4(1) & 21,93 a-fA & $21,03 \mathrm{abA}$ & $6,70 \mathrm{aA}$ & $7,00 \mathrm{abA}$ & 2,31 & 1,98 & 2,51 & 3,15 \\
\hline HWI 4(2) & 24,16 a-fA & $24,88 \mathrm{abA}$ & $6,80 \mathrm{aA}$ & $7,20 \mathrm{abA}$ & 2,11 & 2,31 & 2,49 & 2,56 \\
\hline HWI 4(3) & 24,80 a-fA & $25,74 \mathrm{abA}$ & $6,90 \mathrm{aA}$ & $7,20 \mathrm{abA}$ & 2,58 & 1,85 & 4,06 & 2,35 \\
\hline HWI 4(4) & $26,48 \mathrm{~b}-\mathrm{gA}$ & $26,05 \mathrm{abA}$ & $7,00 \mathrm{aA}$ & $7,25 \mathrm{abA}$ & 1,98 & 1,73 & 2,86 & 1,95 \\
\hline HWI 5(1) & $26,53 \mathrm{~b}-\mathrm{gA}$ & $26,55 \mathrm{abA}$ & $7,05 \mathrm{aA}$ & $7,35 \mathrm{abA}$ & 2,01 & 1,72 & 3,26 & 2,23 \\
\hline HWI 5(4) & $27,90 \mathrm{c}-\mathrm{gA}$ & $27,28 \mathrm{abA}$ & $7,30 \mathrm{aA}$ & $7,45 \mathrm{abA}$ & 1,78 & 1,63 & 2,10 & 2,41 \\
\hline HWI 8(6) & $28,25 \mathrm{c}-\mathrm{gA}$ & $28,13 \mathrm{abA}$ & $7,50 \mathrm{aA}$ & $7,60 \mathrm{abA}$ & 2,32 & 2,93 & 1,65 & 4,24 \\
\hline BS3 4(5) & $28,70 \mathrm{~d}-\mathrm{gA}$ & $28,25 \mathrm{abA}$ & $7,60 \mathrm{aA}$ & $7,75 \mathrm{abA}$ & 2,64 & 2,60 & 2,53 & 3,21 \\
\hline BS3 5(1) & 28,78 d-gA & $30,25 \mathrm{bA}$ & $7,65 \mathrm{aA}$ & $7,80 \mathrm{abA}$ & 2,85 & 2,82 & 2,89 & 2,44 \\
\hline BS3 5(3) & 30,63 efgA & $32,68 \mathrm{bA}$ & $7,70 \mathrm{aA}$ & 7,95 abA & 2,60 & 3,02 & 2,14 & 3,41 \\
\hline BS3 5(4) & $31,35 \mathrm{fgA}$ & $32,73 \mathrm{bA}$ & $7,80 \mathrm{aA}$ & $7,95 \mathrm{abA}$ & 4,17 & 2,88 & 2,74 & 3,48 \\
\hline KTK 8(4) & $31,85 \mathrm{fgA}$ & $33,00 \mathrm{bA}$ & $7,95 \mathrm{aA}$ & $9,35 \mathrm{bA}$ & 2,86 & 2,93 & 2,93 & 2,96 \\
\hline KTK 8(5) & $35,33 \mathrm{gA}$ & $33,68 \mathrm{bA}$ & $8,00 \mathrm{aA}$ & $9,65 \mathrm{bA}$ & 2,71 & 3,00 & 3,57 & 3,84 \\
\hline BNJ 0,05 & \multicolumn{2}{|c|}{10,08} & \multicolumn{2}{|c|}{3,08} & \multicolumn{2}{|c|}{-} & \multicolumn{2}{|c|}{-} \\
\hline
\end{tabular}

Hasil penelitian sebelumnya juga membuktikan isolat rizobakteri Pseudomonas putida, Serratia $s p$ dan $P$. aeruginosa dapat menghasilkan hormon tumbuh asam indol asetat (IAA) (Bano dan Musarrat 2003; Maunuksela, 2004). McMillan (2007) menambahkan bahwa kemampuan rizobakteri sebagai biofertilizer secara asimbiosis yang dapat menambahkan $\mathrm{N}_{2}$ dari udara, melarutkan fosfat, dan mengoksidasi sulfur merupakan karakteristik rizobakteri dalam peranannya sebagai PGPR. Namun kemampuan melarutkan fosfat juga bukan sebagai satu-satunya penentu kemampuan isolat rizobakteri sebagai pemacu pertumbuhan tanaman cabai (Sutariati, 2006).

\section{KESIMPULAN}

Hasil pengujian secara in vitro pada percobaan I, isolat SRK 5(1) yang berasal dari Desa Serulee Kayu dengan nilai 82,22\% terhadap patogen C. capsici dan 71,11\% terhadap patogen $P$. capsici. Hasil percobaan II menunjukkan bahwa rizobakteri yang efektif sebagai pemacu pertumbuhan tanaman (RPPT) terhadap proses perkecambahan benih cabai merah dalam meningkatkan viabilitas dan vigor benih terhadap potensi tumbuh maksimum dan daya berkecambah adalah isolat KTK 8(5) dimana varietas PM999 lebih baik dibandingkan varietas Taro, namun isolat yang berbeda yaitu SRK 5(1), HWI 4(1) dan BS3 5(3) mampu meningkatkan indeks vigor pada varietas Taro yang lebih tinggi dibandingkan dengan varietas PM999. Sedangkan pengaruh perlakuan rizobakteri terhadap pertumbuhan bibit cabai merah belum menunjukkan peningkatan yang signifikan terhadap dua varietas yang dicobakan. 


\section{DAFTAR PUSTAKA}

Agrios, G.N. 2005. Plant Pathology. Academic Press, California.

Agung. 2007. Budidaya Cabai Merah pada Musim Hujan. Agromedia Pustaka, Jakarta.

Bai, Y., B. Pan., T. C. Charles and D. L. Smith. 2002. Coinoculation dose and root zone temperature for plant growth promoting rhizobacteria on soybean (Glycine max L.) grown in soil-less media. Soil Biol Biochem. 34: 1953-1957.

Bano, $\mathrm{N}$ dan J. Musarrat. 2003. Isolation and characterization of phorate bacteria of enviromental and agronomic. Journal Microbiol. 36: 349-353.

Duriat, A. S. N., Gunaeni dan A.W. Wulandari. 2007. Penyakit Penting Tanaman Cabai dan Pengendaliannya. Balai Penelitian Tanaman Sayuran. Pusat Penelitian dan Pengembangan Hortikultura Badan Penelitian dan Pengembangan Pertanian. Lembang, Bandung.

fi/julkaisnt/mat/maunuksela.molecula.pDb. Diakses tanggal : 1 Oktober 2017.

Harman, G. E., C. R. Howell., A.Viterbo., I. Chet and M. Lorito. 2004. Trichoderma speciesopportunistic, avirulent plant symbionts. Nature Reiews Microbiology 2: 43-56.

Ibrahim, A., S. Ilyas dan M. Dyah. 2014. Perlakuan benih cabai (Capsicum annuum L.) dengan rizobakteri untuk mengendalikan Phytophthora capsici meningkatkan vigor benih dan pertumbuhan tanaman. Agrohorti. 2(1): 22 - 30 .

Maunuksela, L. 2004. Molecular and physiological characterization of rhizosphere bacteria and Frankia in forest soil devoid of actinorhiza plants http://www.ethesis.helsinki.

Panjaitan, H., B. Ridwanti dan Yunasfi. 2011. Identifikasi Fungi yang Berkembang pada Batang Sawit (Elaeis Guineensis Jacq.) Pasca Penebangan. Skripsi. Universitas Sumatera Utara, Medan.

Royanti, T. 2017. Eksplorasi dan uji kemampuan rizobakteri sebagai kandidat agens biokontrol dalam menghambat patogen Fusarium oxysporum dan phytium sp. terbawa benih tomat (Lycopersicum esculentum Mill) secara in vitro. Skripsi. Fakultas Pertanian Universitas Syiah Kuala, Banda Aceh.

Sadjad, S. 1999. Dari Benih Kepada Benih. Gramedia Widiasarana, Indonesia.

Safriani. 2015. Daya hambat rizobakteri terhadap pertumbuhan koloni patogen terbawa benih cabai merah secara in vitro dan pengaruhnya terhadap viabilitas benih. Skripsi. Universitas Syiah Kuala. Banda Aceh.

Sutariati, G. A. K dan A. Wahab. 2010. Isolasi dan uji kemampuan rizobakteri indigenous sebagai agensia pengendali hayati penyakit pada tanaman cabai. Jurnal Hortikultura. 20(1): 86-95.

Sutariati, G. A. K., W. Sudarsono dan S. Ilyas. 2006. Pengaruh perlakuan rizobakteri pemacu pertumbuhan tanaman terhadap viabilitas benih serta pertumbuhan bibit tanaman cabai. Jurnal Agronomi. 34(1): 46-54.

Thakuria, D., N.C. Talukdar., C. Goswami., S. Hazarika., R.C. Boro dan M.R. Khan. 2004. Characterization and screening of bacteria from rhizosphere of rice grown in acidic soils of Assam. Current Sci. 86: 978-985. 